\begin{tabular}{|l|l|l||}
\hline \multicolumn{2}{|c|}{ PublisherInfo } \\
\hline \hline PublisherName & $:$ & BioMed Central \\
\hline \hline PublisherLocation & $:$ & London \\
\hline \hline PublisherImprintName & $:$ & BioMed Central \\
\hline \hline
\end{tabular}

\title{
Paracentesis vs TIPS
}

\begin{tabular}{||l|l|l||}
\hline \multicolumn{2}{|c||}{ ArticleInfo } \\
\hline \hline ArticleID & $:$ & 4217 \\
\hline \hline ArticleDOI & $:$ & $10.1186 /$ ccf-2000-5939 \\
\hline \hline ArticleCitationID & $:$ & 5939 \\
\hline \hline ArticleSequenceNumber & $:$ & 76 \\
\hline \hline ArticleCategory & $:$ & Paper Report \\
\hline \hline ArticleFirstPage & $:$ & 1 \\
\hline \hline ArticleLastPage & $:$ & 3 \\
\hline \hline & & RegistrationDate : 2000-9-8 \\
ArticleHistory & $:$ & OnlineDate \\
\hline \hline ArticleCopyright & $:$ & Current Science Ltd2000-8 \\
\hline \hline ArticleGrants & $:$ & \\
\hline \hline ArticleContext & $:$ & 1305422 \\
\hline \hline
\end{tabular}




\section{Keywords}

Ascites, cirrhosis, liver transplantation, outcome, paracentesis, transjugular intrahepatic portosystemic shunt

\section{Comments}

Transjugular intrahepatic portosystemic shunting (TIPS) is a useful treatment modality for patients with cirrhosis and refractory or recurrent ascites. This study contrasts with a smaller study performed by Lebrec and colleagues (see Additional information), showing that TIPS may increase the chance of survival without liver transplantation when compared with large volume paracentesis. The response to treatment was significantly better in the TIPS group, with a reduced requirement for further paracentesis and diuretics. The authors were surprised to find that the incidence of hepatic encephalopathy was no worse with TIPS. They postulate that the negative effects of shunting are compensated for by improvements in renal function and electrolyte balance. TIPS appears to be a safe procedure, which takes approximately $1 \mathrm{~h}$ to perform, although reestablishment of the shunt is a fairly common occurrence.

\section{Introduction}

The treatment options for refractory or recurrent ascites are repeated paracentesis, portosystemic shunt, peritoneovenous shunt and liver transplantation. This study compares transjugular TIPS, which may decrease the formation of ascites and improve renal function, with repeated large volume paracentesis. Paracentesis is effective and safe but has disadvantages, including tense ascites between paracentesis, and bacterial peritonitis.

\section{Methods}


- 60 patients, with cirrhosis and refractory or recurrent ascites, randomised to TIPS (29) or paracentesis (31)

- Primary outcome was survival without liver transplant

- Requirement for paracentesis, incidence of encephalopathy, and creatinine clearance was assessed in both groups

- TIPS could be offered for rescue therapy in the paracentesis group

- Mean follow up period was nearly 4 years

\section{Results}

Baseline characteristics were similar. Eleven patients in the TIPS group required reestablishment of the shunt, and five required a further reestablishment. There were no procedure-related deaths. In the paracentesis group 23 patients died and 15 died in the TIPS group (not significant). In the paracentesis group 10 patients received rescue TIPS. Paracentesis was performed on 21 occasions in the TIPS group and 280 times in the paracentesis group. Over the first 6 month follow-up period, the requirement for spironolactone was significantly reduced in the TIPS group. After 6 months, ascites had been eliminated in 15 patients in the TIPS group and five patients in the paracentesis group $(P=0.001)$. There were no differences between the groups in the incidence of hepatic encephalopathy, changes in liver function, and creatinine clearance over the follow-up period.

\section{Additional information}

Lebrec D, Giuily N, Hadengue A, Vilgrain V, Moreau R, Poynard T, Gadano A, Lassen C, Benhamou JP, Erlinger S: Transjugular intrahepatic portosystemic shunts: comparison with paracentesis in patients with cirrhosis and refractory ascites: a randomized trial. $J$ Hepatol 1996, 25:135-144.

\section{References}

1. Rossle M, Ochs A, Gulberg V, Siegerstetter V, Holl J, Debert P, Olschewski M, Reiser M, Gerbes A: A comparison of paracentesis and transjugular intrahepatic portosystemic shunting in patients with ascites. N Engl J Med. 2000, 342: 1701-1707.

This PDF file was created after publication. 